В.А. Таршин, М.Ю. Дергоусов, Г.В. Акулінін

Харківський національний університет Повітряних Сил ім. І. Кожедуба, Харків

\title{
МЕТОД КОРЕКЦІЇ ТРАЄКТОРІЇ ПОЛЬОТУ ЗАСОБУ ДОСТАВКИ РЯТУВАЛЬНОГО СПОРЯДЖЕННЯ З УРАХУВАННЯМ РОЗМИТТЯ ПОТОЧНИХ ЗОБРАЖЕНЬ ОБ'ЄКТА ПРИВ'ЯЗКИ
}

У ряді випадків надзвичайних ситуацій виникає необхідність термінової доставки рятувального спорядження, продовольства, засобів першої необхідності у важкодоступні райони. Запропонований варіант спрямований на забезпечення швидкої $і$ точної доставки засобів порятунку в райони, де люди потрапили в екстремальні умови $і$ зазнали лиха в віддалених безлюдних районах, в тому числі в районах з різними фізичними та кліматичними умовами. Для изього можуть бути застосовані безпілотні літальні апарати одноразового використання. За засіб доставки рятувального спорядження розглядається керований снаряд. В статті запропоновано метод корекиії траєкторії польоту засобу доставки рятувального спорядження шляхом формування вирішальної функції кореляційно-екстремальної системи навігації, щзо на відміну від відомих, дозволяє врахувати спотворення поточного зображення поверхні візування, які виникають внаслідок особливостей руху в процесі польоту.

Ключові слова: кореляиійно-екстремальна система навігачії, високоточне наведення, засіб доставки рятувального спорядження, керований снаряд.

\section{Вступ}

Постановка проблеми. Ефективність надання допомоги у критичних ситуаціях у важкодоступних, зокрема високогірних, морських районах, значною мірою залежить від швидкості та точності доставки рятувального спорядження, медичних засобів, потрібних запасів постраждалим. У таких випадках ефективним може бути застосування засобів достав- ки одноразового використання, які конструктивно являють собою керований снаряд (ракету) (рис. 1) та мають оптико-електронну систему навігації для забезпечення потрібної точності доставки вантажу у задану точку [1].

Пропоноване рішення особливо ефективне у випадках, коли часовий ресурс істотно менший часу підходу штатних рятувальних (транспортних) засобів (підльоту літака або підходу корабля) [2].

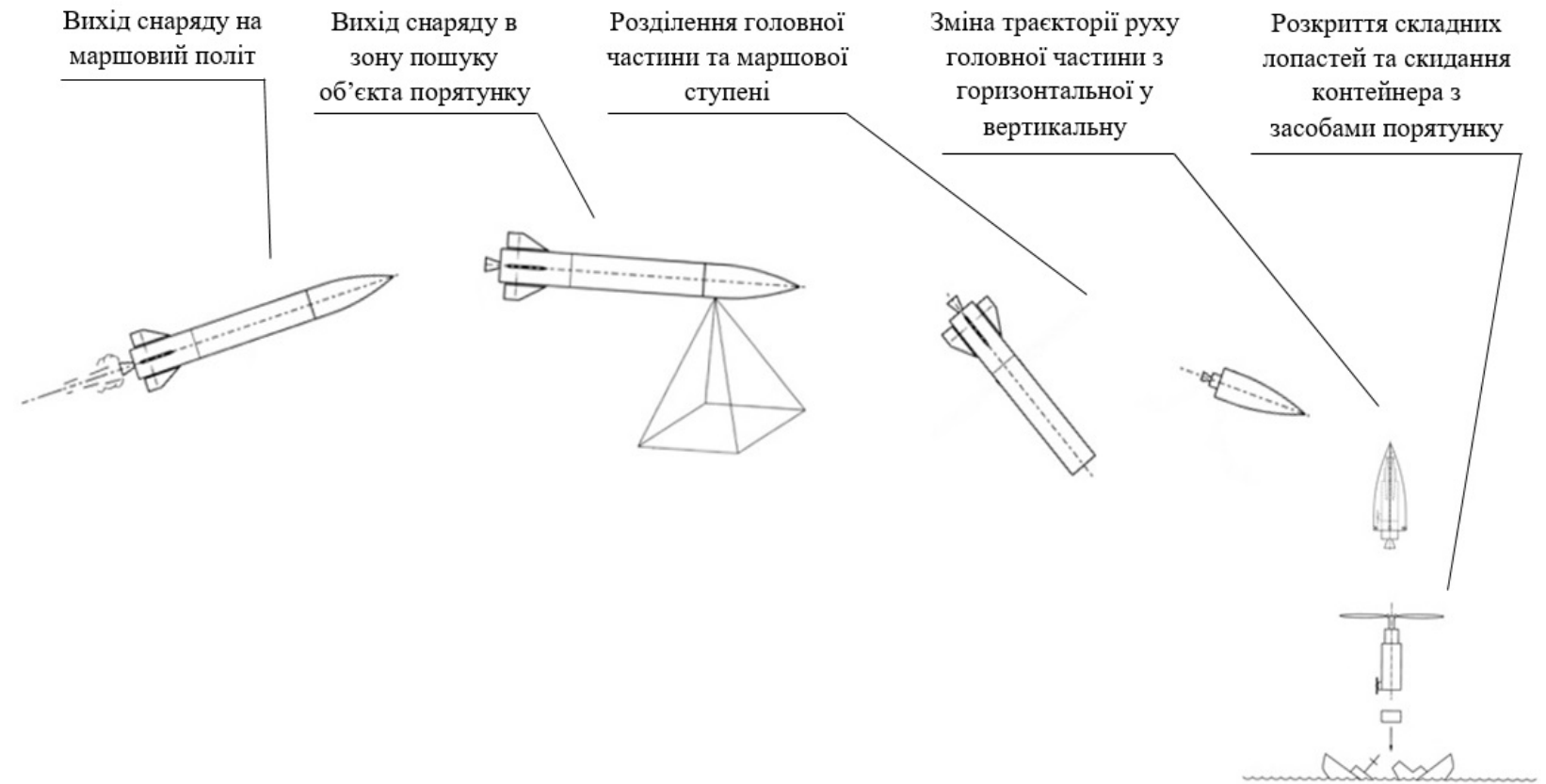

Рис. 1. Спосіб оперативної доставки засобів порятунку 
Стабілізація орієнтації, простого за конструкцією керованого снаряда у просторі, досягається наявністю у нього маршової інерціальної системи навігації, органів керування (корекції) у процесі польоту та наданням йому обертального руху навколо повздовжньої осі.

Забезпечення потрібної точності функціонування інерційної системи навігації здійснюється за рахунок більш точної оптико-електронної кореляційно-екстремальної системи навігації (КЕСН). Проте, обертальний рух снаряда навколо повздовжньої осі обумовлює зміну орієнтації отриманого поточного зображення (ПЗ) КЕСН по відношенню до еталонного зображення (Е3).

Для усунення спотворень поточного зображення об'єкта прив'язки на поверхні Землі, обумовлених обертальним рухом керованого снаряду навколо своєї осі, що отримані оптичними бортовими датчиками, розроблено метод усунення розмиття контурів об'єктів прив'язки на ПЗ.

Розроблений метод дозволяє досягти зменшення ефекту розмиття ПЗ оптико-електронної КЕСН внаслідок обертального руху керованого снаряда, покращити міру різкості ПЗ при зміні швидкості обертання снаряду на різних ділянках траєкторії польоту та забезпечити умови формування унімодальної вирішальної функції (ВФ) як команди на корекцію траєкторії польоту керованого снаряда.

Аналіз останніх досліджень і публікацій. Перспективність застосування КЕСН обумовлена великою кількістю досліджень сучасних авторів, аналіз яких наведений у роботах [3-6]. Останні результати досліджень методів формування вирішальної функції КЕСН наведені у роботах [7-8].

В роботах [9-10] розглядались моделі процесу функціонування КЕСН що дозволяють зменшити вплив масштабних спотворень, обумовлених невідповідністю висоти польоту об’єкта наведення над районом прив'язки та перспективних спотворень [11], обумовлених невідповідністю кутів візування оптичних датчиків, сформованим заздалегідь еталонним зображенням. Крім того, в роботі [10] розглядався варіант геометричних спотворень, обумовлений результатом природних або катастрофічних наслідків.

Сучасні підходи до вибору об'єктів прив'язки та методи формування еталонних зображень наведені в роботі [12].

Однак, спотворення зображень, обумовлені обертанням керованого снаряду навколо своєї осі, наслідком чого є розмиття контурів об'єктів та фонів на поточному зображенні поверхні візування, у відомих роботах не розглядалось. Також потребують конкретизації показники, за якими можна було б оцінювати ступінь розмиття поточних зображень.
Мета статті - розробка методу корекції траєкторії польоту засобу доставки рятувального спорядження для забезпечення високоточного місцевизначення системи навігації шляхом усунення розмиття об'єктів прив'язки на поточному зображенні поверхні візування.

\section{Виклад основного матеріалу}

В процесі обертання керованого снаряду навколо своєї осі виникає розузгодження ПЗ відповідно до сформованого заздалегідь ЕЗ. Усунення такої розбіжності може бути забезпечене шляхом усунення спотворень, обумовлених розмиттям контурів об'єктів та фонів ПЗ на поверхні візування (ПВ). Відповідно виникає необхідність в вирішенні наступних задач:

- дослідження впливу розмиття контурів об'єктів прив'язки ПЗ на формування ВФ КЕСН.

- формування ВФ КЕСН по критерію максимуму коефіцієнта взаємної кореляції (КВК) шляхом усунення розмиття контурів об'єктів прив'язки на ПЗ.

При моделюванні процесу формування ПЗ 3 ефектом розмиття контурів об'єктів та фонів, будемо розглядати випадки, коли об'єкт прив'язки знаходиться в центрі та на краю зображення, а ПЗ має різний ступінь розмиття, в залежності від швидкості обертання керованого снаряду. Для кількісної оцінки розмиття зображення застосовується міра різкостi [13].

Оскільки, для роботи оптико-електронної $\mathrm{KECH,} \mathrm{в} \mathrm{даному} \mathrm{випадку,} \mathrm{використовується} \mathrm{напів-}$ тонове зображення, кожен піксель якого, може приймати 256 різних умовних значень яскравості від 0 до 255, то і значення міри різкості визначаються у тому ж діапазоні.

При оцінці впливу якості поточного зображення на результат формування вирішальної функції КЕСН шляхом математичного моделювання розглядались ПЗ з різною мірою різкості. Для цього застосовувалось кругове розмиття поточного зображення програмним способом, шляхом повороту ПЗ на кути від 0 до 10 градусів.

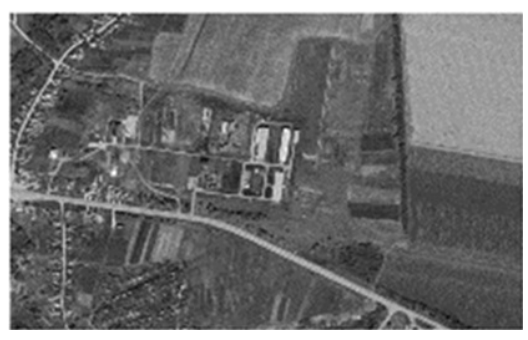

Рис. 2, а. Розмиття поточного зображення при повороті ПЗ на кут $0^{\circ}$ 


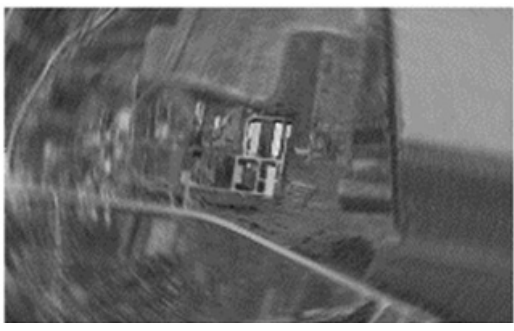

Рис. 2, б. Розмиття поточного зображення при повороті ПЗ на кут $2^{\circ}$

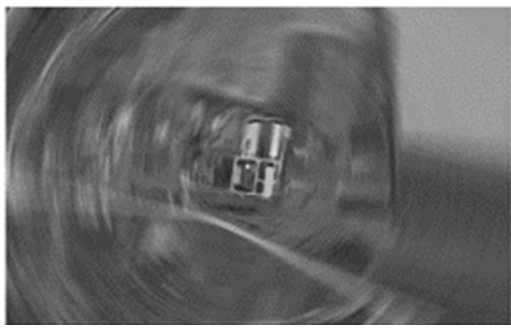

Рис. 2, в. Розмиття поточного зображення при повороті ПЗ на кут $5^{\circ}$

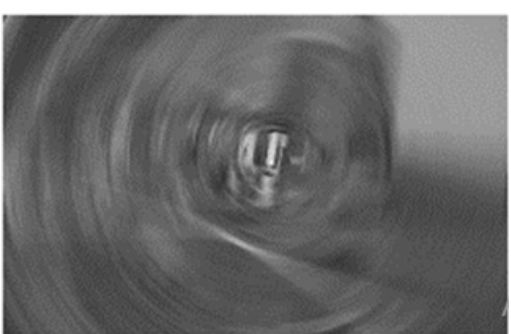

Рис. 2, г. Розмиття поточного зображення при повороті ПЗ на кут $10^{\circ}$

Джерело: розроблено авторами.

В той же час при підготовці Е3 розглядалися зображення при повороті кута від -10 до 10 градусів. Об'єкт однократної прив'язки в даному прикладі розміщений в центрі зображення (рис. 3). У випадку декількох прив'язок на різних висотах створюється матриця еталонів, де кожен рядок матриці відповідає обраному еталонному зображенню на різних висотах.

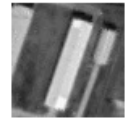

a

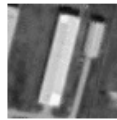

б

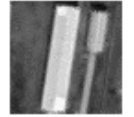

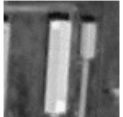

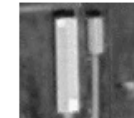

Д
Рис. 3. Еталонне зображення при повороті кута на $\mathrm{a}-10^{\circ} ; 6-5^{\circ} ;$ в $-0^{\circ} ;$ г $-5^{\circ} ;$ д $-10^{\circ}$

Джерело: розроблено авторами.

За результатами моделювання, відповідно до заданих умов формування ПЗ на ПВ з нормальною об'єктовою насиченістю, максимальний КВК спостерігається при повному суміщені ПЗ та ЕЗ. Такі умови можуть бути забезпечені при відсутності повороту та максимально можливій мірі різкості. Проте, в процесі польоту, внаслідок кругового обертання керованого снаряду навколо своєї осі зі змінною швидкістю, відбувається розмиття контурів об'єктів і фонів на поточному зображенні. Для оцінки якості сформованого поточного зображення для об'єкта прив'язки, що здійснює у процесі руху обертальний рух навколо своєї осі зі змінною швидкістю необхідно оцінити його міру різкості [14]:

$$
H_{i}=\operatorname{tg} \alpha=\frac{G}{w},
$$

де $i$ - кількість крайових пікселів на зображенні, $w$ ширина перепаду, $G$ - різниця між значеннями яскравості пікселів, що позначається $a$ та $b$.

$$
H_{i}=\operatorname{tg} \alpha=\frac{I(a)-I(b)}{w} .
$$

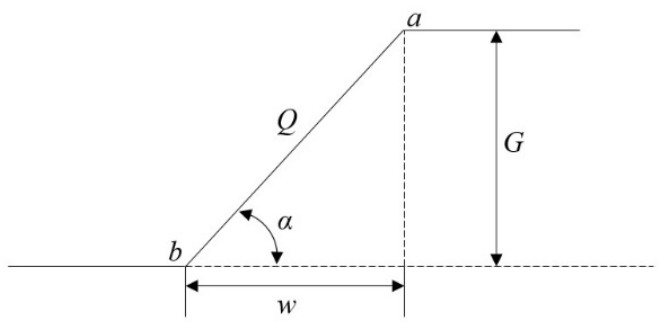

Рис. 4. Схема обчислення кута нахилу Джерело: розроблено авторами.

Мipу різкості зображення в такому випадку будемо розглядати як ступінь розмиття межі між двома сусідніми ділянками зображення з різною яскравістю. У випадку, коли об'єкт прив'язки знаходиться близько до центру поточного зображення, спотвореного обертальним рухом (рис. 5-6), застосування відомих методів порівняння Е3 та ПЗ може забезпечити отримання унімодальної ВФ при відносно невеликих значеннях розмиття. Проте, якщо об'єкт прив'язки на поточному зображенні зміщується ближче до краю (рис. 7-8), то, як показали результати досліджень, вирішальна функція стає багатомодовою і не забезпечує можливість однозначного місцевизначення. В такому випадку виникає необхідність пошуку можливих шляхів зменшення впливу спотворень на результат формування вирішальної функції як команди на корекцію траєкторії польоту снаряду.

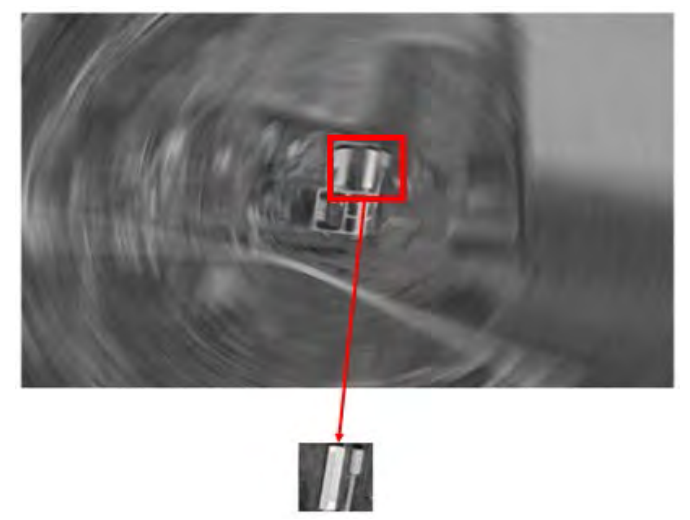

Рис. 5. Зображення, спотворене обертальним рухом керованого снаряду у порівнянні з об'єктом прив'язки (Е3), розташованим в центрі П3 


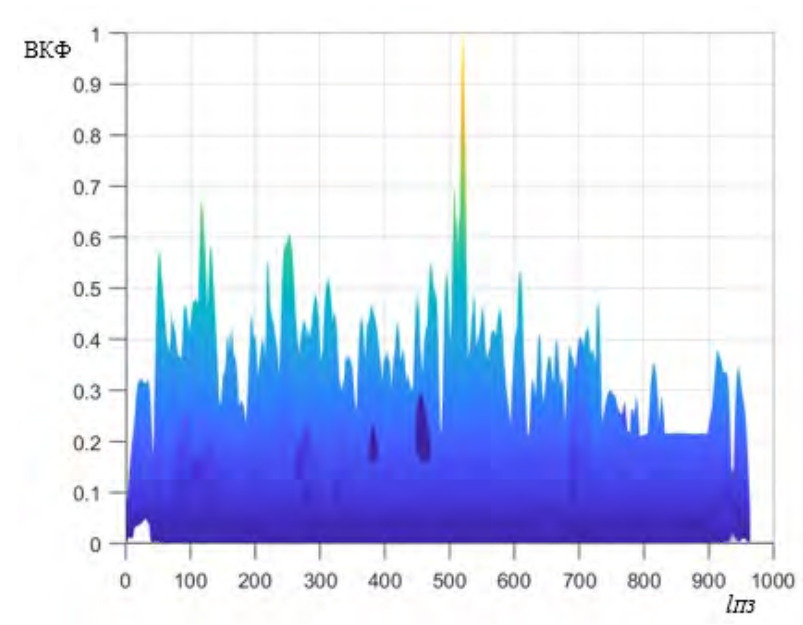

Рис. 6. Нормована взаємна кореляційна функція при визначенні об'єкта прив'язки у центрі ПЗ Джерело: розроблено авторами.

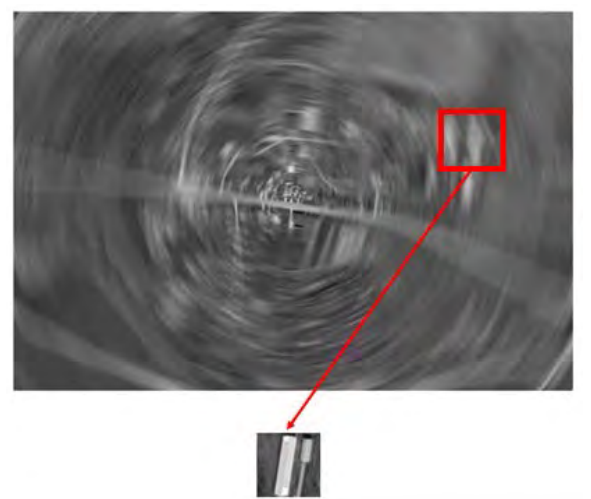

Рис. 7. Поточне зображення, спотворене у результаті обертального руху керованого снаряду у порівнянні з об'єктом прив'язки (Е3) розташованим на краю ПЗ Джерело: розроблено авторами.

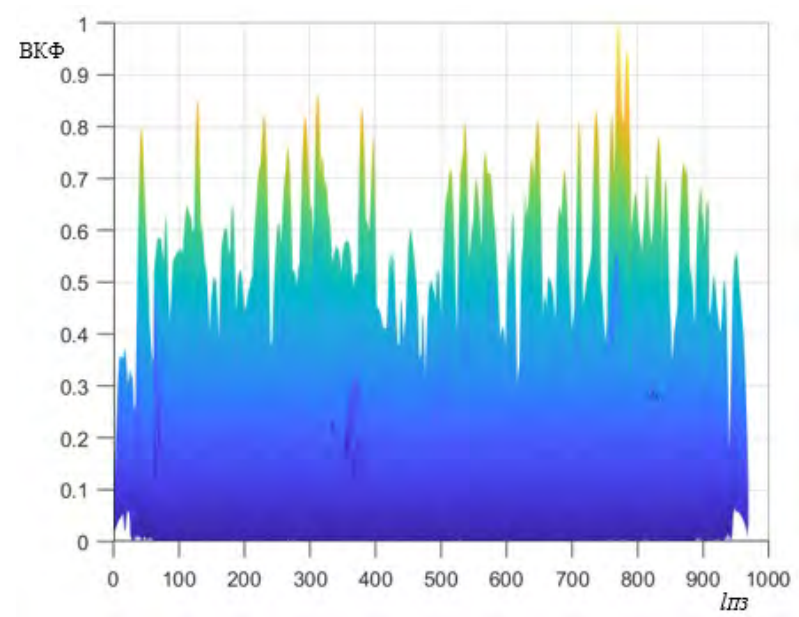

Рис. 8. Нормована взаємна кореляційна функція при визначенні об'єкта прив'язки на краю поточного зображення

Джерело: розроблено авторами.

Спотворення, обумовлені обертанням снаряду навколо своєї осі, призводять до розмиття контурів об'єкта прив'язки на ПЗ $m_{1} \times n_{1}$ відносно вихідного $m \times n$, представленого на ЕЗ.
При виділенні об'єкта прив'язки на ПЗ ПВ, фон розглядаємо як постійну складову яскравості ПЗ, завдяки чому досягаються високі значення контрасту зображення. Виходячи з цього, яскравість елементів об'єктів та фонів, зображення $S_{П 3}(i, j)$ із визначеними координатами $(i, j)$ можна описати залежністю:

$$
S_{\Pi 3}^{\prime}(i, j)=S_{\Pi 3}(i, j, H) .
$$

Така модель представлення неспотвореного зображення ПЗ дозволяє оцінити міру різкості поточного зображення при відсутності спотворень для існуючого фоново-об'єктового складу. Де значення $H \epsilon$ максимальним для заданих умов спостереження поверхні візування.

В умовах спотворень модель зображення зручно представити у вигляді:

$$
S_{\Pi 3}^{\prime}(i, j)=S_{\Pi 3}(i, j, H, \theta) .
$$

Така модель ПЗ справедлива у разі, якщо спотворення об'єктів прив'язки та фону відсутні, а поточне зображення відповідає вихідному. В іншому випадку модель ПЗ повинна враховувати спотворення, обумовлені обертальним рухом керованого снаряду навколо своєї осі, а саме розмиття контурів об'єкту прив'язки та фону. Тоді модель ПЗ матиме вигляд:

$$
S_{\Pi 3}^{\prime}(i, j, t)=S_{\Pi 3}(i, j, H)+\Delta F_{c}(i, j, t, H, \theta),
$$

де $\Delta F_{c}(i, j, t, H, \theta)$ - зміна яскравості поточного зображення за рахунок спотворення, обумовленого наявністю кута розузгодження $\theta$ орієнтації об'єкта прив'язки ПЗ відносно ЕЗ.

В такому випадку, спотворення, обумовлені розмиттям контурів об'єктів на поточному зображенні, будуть надавати негативний вплив на результат формування вирішальної функції $\left(\mathbf{R}_{B \Phi}(t, \mathbf{r})\right)$, яка визначається функціоналом $\mathbf{F}_{B O}$ порівняння еталонного зображення об'єкта прив'язки $\mathbf{S}_{E 3}$ та спотвореного поточного зображення $\mathbf{S}_{П 3}^{\prime}$, отриманого з борта керованого снаряду у поточний момент часу:

$$
\mathbf{R}_{B \Phi}(t, \mathbf{r})=\mathbf{F}_{B O}\left(S_{\Pi 3}^{\prime}(t), S_{E 3}\right),
$$

де $\mathbf{R}_{B \Phi}$ - вирішальна функція-матриця, яка формується КЕСН;

$t$ - поточний час;

$\mathbf{r}=\left\|r_{i}\right\|-$ вектор параметрів зсуву представле-

них у матричному вигляді спотвореного ПЗ $\left(S_{\Pi 3}^{\prime}(t)\right)$ та Е3 $\left(S_{E 3}\right)$ у картинній площині;

$\mathbf{F}_{B O}$ - оператор вторинної обробки КЕСН;

$S_{\Pi 3}^{\prime}(t)$ - спотворене ПЗ $S_{\Pi 3}$ внаслідок поступального та обертального руху керованого снаряду.

Сутність запропонованого методу корекції траєкторії польоту керованого снаряду з урахуванням 
впливу спотворень, обумовлених розмиттям контурів об'єктів прив'язки на ПЗ полягає у одночасному формуванні сукупності часткових ВФ. При цьому, максимальне значення часткової ВФ буде забезпечуватись тоді, коли:

$$
\left|\Theta_{E 3}-\Theta_{\Pi 3}\right| \rightarrow \min .
$$

Виконання цієї умови дозволить забезпечити мінімізацію впливу спотворень, а також дозволить отримати максимальне значення міри різкості зображення.

На рис. 9 наведені результати розрахунків залежності коефіцієнта взаємної кореляції $K(H)$ Е3 та ПЗ від кута повороту Е3 $\Theta$ при різній мірі різкості ПЗ $H$ за параметром яскравості. Розрахунки показали, що значення різкості Е3 дорівнює 50. У той же час збільшення швидкості обертання керованого снаряду в процесі польоту навколо своєї осі, призводить до зменшення міри різкості П3. 3 аналізу представлених результатів бачимо, що при повороті ПЗ на кути $2^{\circ}, 3^{\circ}, 5^{\circ}, 7^{\circ}, 10^{\circ}$ значення міри різкості $H \in 42,37,22,13,5$ відповідно. Таким чином, при повороті ПЗ на кут, що дорівнює $2^{\circ}-3^{\circ}$ значення міри різкості має незначні відхилення у порівнянні з вихідним зображенням, що дозволяє отрима- ти унімодальну вирішальну функцію шляхом застосування відомих методів.

Проте, при повороті ПЗ на кут у $7^{\circ}-10^{\circ}$, значення КВК зменшується майже у 1.5 рази, а міра різкості ПЗ $<0.5$ відносно Е3. В такому випадку значення бічних залишків може перевищувати значення головного максимума КВК, що в свою чергу призводить до великої похибки місцевизначення системи навігації засобу доставки рятувального спорядження. За результатами досліджень встановлено, що у випадку, коли міра різкості зображення $H<0.6$, а кут повороту ПЗ $\Theta>5^{0}$, розмиття ПЗ набуває вигляду, що не дає можливості здійснювати прив'язку.

Як показали розрахунки, покращити значення КВК в такому випадку можливо завдяки застосуванню методів відновлення розмиття зображень. Таким чином, при розрахунках був застосований фільтр Люсі-Річардсона [15], що в свою чергу дозволило підвищити міру різкості більш ніж у 2 рази та покращити якість зображення в цілому. Відновлення зображення в такому випадку дає можливість для отримання унімодальної ВФ.

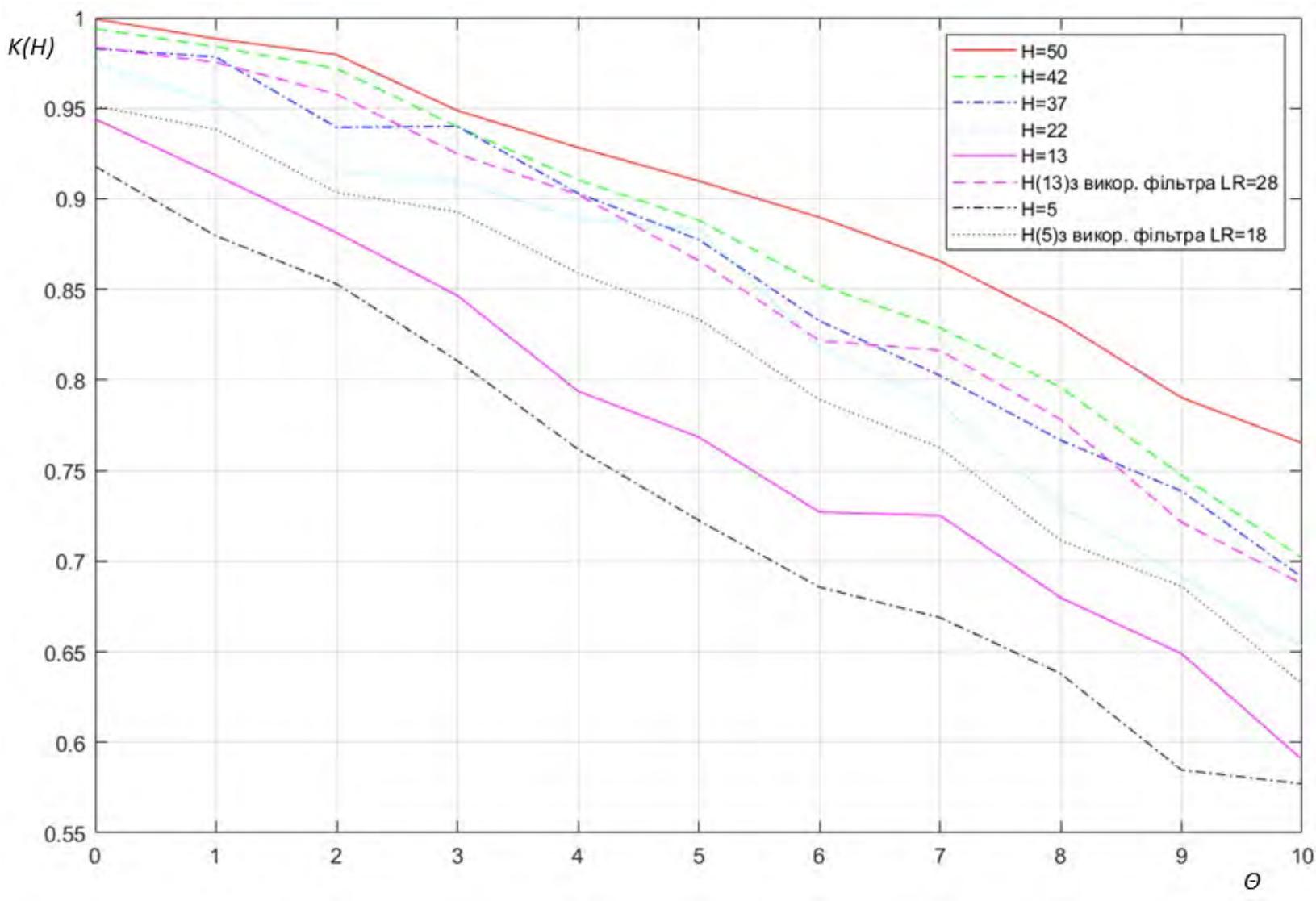

Рис. 9. Залежність коефіцієнта взаємної кореляції $K H(\quad$ ) $\quad$ Е3 та ПЗ від кута повороту Е3 $\Theta$ при різній мірі різкості ПЗ $H$ за параметром яскравості

Джерело: розроблено авторами. 
Для досягнення необхідних результатів у якості удосконаленої системи навігації розглядається багатоканальна КЕСН.

Формування часткових ВФ відбувається в кожному каналі, що відповідає заданому куту повороту, за параметром яскравості та контрасту. Для забезпечення таких вимог, необхідно, щоб виконувалась умова унімодальності функції. У випадку, коли функція $є$ багатомодовою, використовуємо добуток значень ВФ за параметром яскравості та контрасту.

\section{Висновки}

Забезпечення високоточного місцевизначення системи навігації засобу доставки рятувального спорядження, в якості якого розглядається керований снаряд, можливе завдяки застосуванню розробленому методу, що дозволяє врахувати особливості польоту керованого снаряду.

Даний метод передбачає оцінку міри різкості П3, відновлення інформативних параметрів на поточному зображенні, а також усунення ефекту розмиття поточного зображення оптико-електронної КЕСН внаслідок обертального руху керованого снаряда та забезпечення умов формування унімодальної вирішальної функції КЕСН як команди на корекцію траєкторії польоту керованого снаряда.

\section{Список літератури}

1. Герасимов С.В. Дослідження високоточних систем навігації літальних апаратів за наземними орієнтирами / С.В. Герасимов, А.М. Гричанюк, О.О. Журавльов // Збірник наукових праць Харківського національного університету Повітряних Сил. - 2017. - № 5(54). - С. 48-53.

2. Журавльов О.О. Оцінка маневрених можливостей модельної головної частини, що управляється, після ії відокремлювання в польоті від реактивного снаряда / О.О. Журавльов, Ю.М. Осіпов, С.В. Орлов // Збірник наукових праць Харківського національного університету Повітряних Сил. - 2016. - № 4(49). - С. 38-41.

3. Белов А. Совершенствование крылатой ракеты “Томахок” / А. Белов, А. Валентинов // Зарубежное военное обозрение. - 1996. - № 11. - С. 44-49.

4. Щербинин В.В. Построение инвариантных корреляционно-экстремальных систем навигации и наведения летательных аппаратов / В.В. Щербинин. - М.: Изд-во МГТУ им. Н.Э. Баумана, 2011. - 230 с.

5. Баклицкий В.К. Корреляционно-экстремальные методы навигации и наведения / В.К. Баклицкий. - Тверь: ТО “Книжный клуб”, 2009. - 360 с.

6. Кожушко Я.Н. Алгоритмы совмещения изображений в корреляционно-экстремальных системах навигации летательных аппаратов / Я.Н. Кожушко // Системи обробки інформації. - 2008. - № 1. - С. 25-28.

7. Сотніков О.М. Проблеми та напрямки розвитку кореляційно-екстремальних систем наведення керованих літальних апаратів / О.М. Сотніков, В.А. Таршин, П.В. Опенько // Сучасні інформаційні технології у сфері безпеки та оборони. - 2013. - № 3(18). - С. 93-96.

8. Методика оценки информативности исходных изображений для высокоточных корреляционно-экстремальных систем навигации / В.А. Таршин, А.М. Сотников, Р.Г. Сидоренко, А.В. Мезенцев // Системи обробки інформації. - 2015. - № 10. - С. 60-63.

9. Метод коррекции перспективных искажений текущих изображений в радиометрических системах навигации / В.И. Антюфеев, В.Н. Быков, А.М. Гричанюк, Я.Н. Кожушко // Системи обробки інформації. - 2005. - № 4. - С. 7 15 .

10. Срьоміна Н.С. Метод прив'язки безпілотних літальних апаратів з використанням кореляційно-екстремальних систем навігації в умовах появи хибних об’єктів на поточному зображенні: автореф. дис. ... канд. техн. наук: 05.12.17 "Радіотехнічні та телевізійні системи" / Н.С. Срьоміна. - Харків, 2018. - 20 с.

11. Сотніков О.М. Метод формування вирішальної функції кореляційно-екстремальних систем навігації в умовах перспективних спотворень поточних зображень / О.М. Сотніков, В.А. Таршин, Н.С. Єрьоміна // Збірник тез доповідей наукової конференції Харківського національного університету Повітряних Сил ім. І. Кожедуба "Новітні технології для захисту повітряного простору”. - Харків, 12-13 квітня 2017 р. - С. 414-415.

12. Таршин В.А. Подготовка эталонных изображений для высокоточных корреляционно-экстремальных систем навигации на основе использования прямого корреляционного анализа / В.А. Таршин, А.М. Сотников, Р.Г. Сидоренко // Наука і техніка Повітряних Сил Збройних Сил України. - 2015. - № 2. - С. 69-73.

13. Монич Ю.И. Мера оценки резкости цифрового изображения / Ю.И. Монич, В.В. Старовойтов // Доклады Белорусского государственного университета информатики и радиоэлектроники. - 2011. - № 1(55). - С. 80-84.

14. Кольцов П.П. Оценка размытия изображения / П.П. Кольцов // Компьютерная оптика. - 2011. - № 1(35). C. $95-96$.

15. Восстановление расфокусированных и смазанных зображений [Електронний ресурс] // Мир кибербезопасности в ресурсах. - Режим доступу: https://habr.com/ru/post/136853/. 
Відомості про авторів:

Таршин Володимир Анатолійович

доктор технічних наук доцент

начальник кафедри

Харківського національного університету

Повітряних Сил ім. І. Кожедуба,

Харків, Україна

https://orcid.org/0000-0001-7059-6354

\section{Дергоусов Михайло Юрійович}

ад'юнкт

Харківського національного університету

Повітряних Сил ім. І. Кожедуба,

Харків, Україна

https://orcid.org/0000-0002-5126-6787

Акулінін Гліб Васильович

кандидат технічних наук доцент

доцент

Харківського національного університету

Повітряних Сил ім. І. Кожедуба,

Харків, Україна

https://orcid.org/0000-0002-7313-9164
Information about the authors:

Volodymyr Tarshyn

Doctor of the Technical Sciences Associate Professor

Head of Department

of Ivan Kozhedub Kharkiv National

Air Force University,

Kharkiv, Ukraine

https://orcid.org/0000-0001-7059-6354

Mykhailo Derhousov

Doctoral Student of Ivan Kozhedub

Kharkiv National

Air Force University,

Kharkiv, Ukraine

https://orcid.org/0000-0002-5126-6787

Hlib Akulinin

Candidate of the Technical Sciences Associate Professor

Senior Lecturer

of Ivan Kozhedub Kharkiv National

Air Force University,

Kharkiv, Ukraine

https://orcid.org/0000-0002-7313-9164

\section{МЕТОД КОРРЕКЦИИ ТРАЕКТОРИИ ПОЛЕТА СРЕДСТВА ДОСТАВКИ СПАСАТЕЛЬНОГО СНАРЯЖЕНИЯ С УЧЕТОМ УСТРАНЕНИЯ РАЗМЫТИЯ ТЕКУЩИХ ИЗОБРАЖЕНИЙ КОРРЕЛЯЦИОННО-ЭКСТРЕМАЛЬНОЙ СИСТЕМЫ НАВИГАЦИИ}

В.А. Таршин, М.Ю. Дергоусов, Г.В. Акулинин

Для обеспечения высокоточного местоположения системы навигации средства доставки спасательного снаряжения разработан метод формирования решающуей функции корреляционно-экстремальной системы навигации. Предложено использовать многоканальную корреляционно-экстремальную систему навигации, в которой формирование частных решающих функций осуществляется в канале, соответствующем заданному углу поворота эталонного изображения, по параметру яркости и контраста или их совокупности. Для оценки степени размытия текущего изображения определена количественная мера качества изображения, оценена его резкость и контраст. Также определень условия, при которых достигается максимальный коэффицчиент взаимной корреляции текущего и эталонного изображений. В процессе вращения снаряда вокруг продольной оси возникает рассогласование текущего изображения (ТИ) относительно сформированного заранее эталонного изображения (ЭИ). Устранение такого рассогласования может быть обеспечено путем устранения искажений, обусловленных размытием контуров объектов и фонов ТИ на поверхности визирования (ПВ). Для оценки степени размытия определено количественную меру качества изображения. Таким значением выступает степень резкости. Чтобы дать абсолютную оценку изображению оценена его резкость и контраст. Для достижения необходимых результатов в качестве усовершенствованной системь навигации рассматривается многоканальная корреляционно-экстремальная система навигации. Формирование частньх решающих функций происходит в каждом канале, что соответствует заданному углу поворота, по параметру яркости и контраста. По результатам исследований статистического моделирования с использованием ТИ ПВ разного качества и фоново-объектового состава установлены значения меры резкости и угла поворота, при которых становится невозможным осуцествлять привязку. В таком случае, необходимо применять метод восстановления искаженных изображений.

Ключевые слова: коррелячионно-экстремальная система навигачии, высокоточное наведениее, средство доставки спасательного снаряжения, управляемый снаряд.

\section{CORRECTION METHOD OF THE FLIGHT TRAJECTORY OF THE DELIVERY METHOD RESCUE EQUIPMENT TAKING INTO ACCOUNT REMOVING THE DISTURBANCE OF CURRENT IMAGES OF THE CORRELATION-EXTREME NAVIGATION SYSTEM}

V. Tarshyn, M. Derhousov, H. Akulinin

To ensure the high-precision location of the navigation system of the rescue equipment delivery vehicle, a method has been developed for forming the decisive function of the correlation-extreme navigation system. It is proposed to use a multichannel correlation-extreme navigation system in which the formation of private decision functions is carried out in a channel corresponding to a given angle of rotation of the reference image according to the brightness and contrast parameter or their combination. To assess the degree of blurring of the current image, a quantitative measure of image quality is determined, its sharpness and contrast are estimated. The conditions under which the maximum coefficient of mutual correlation of the current and reference images are achieved are also determined. During the rotation of the projectile around the longitudinal axis, a mismatch of the current image (CI) with respect to the pre-formed reference image (RI) occurs. The elimination of such a mismatch can be achieved by eliminating distortions caused by blurring of the contours of objects and backgrounds of CI on the surface of sight. To assess the degree of blur, a quantitative measure of image quality is determined. This value is the degree of sharpness. To give an absolute assessment of the image, its sharpness and contrast were evaluated. To achieve the required results, a multi-channel correlation-extreme navigation system is considered as an improved navigation system. The formation of private decision functions takes place in each channel, which corresponds to a given angle of rotation, according to the brightness and contrast parameter. According to the results of studies of statistical modeling using CI on the surface of sight of different quality and background - object composition, the values of the measure of sharpness and the angle of rotation at which it becomes impossible to link are established. In this case, it is necessary to apply the method of restoring the distorted images.

Keywords: correlation-extreme guidance system, precision guidance, rescue equipment delivery vehicle, guided projectile. 